a delight to work with. He was that rare person who combined brilliance and seriousness of purpose with humor and humanity.

Visits to his afternoon office hours at the institute often attracted those from neighboring offices and became wonderful, far-ranging discussions of books and ideas, often encouraged by vodka and extending into snowy evenings. Dinners at his home were similarly relaxed, and even in the hardest times of defitsit, he and his wife, Natasha, managed to load their table with delicacies they could not afford. His good cheer and the value he placed on friendship extended to his trips to the United States. Rather than hunt for scarce western goods to take home, Andrei would rather attend a Siegelbaum son's soccer game or giggle as he played endless games of fetch with Arch Getty's beagle, Earl.

Time with him and Natasha was always a treat, full of heart-to-heart conversations with no subjects excluded. As his health began to decline, Natasha would forbid vodka at the table, limiting Andrei to a single beer. In that way he had, Andrei would complain with good nature, frown while smiling, and then do exactly what Natasha told him to do. We think she was the only person on the planet whom he obeyed, although he did sometimes sneak around to enjoy a forbidden cigarette.

Russian studies is poorer without Andrei Konstantinovich, and our lives are smaller and sadder. We will miss him tremendously.

\author{
J. ARCH GETTY \\ University of California, Los Angeles \\ LEWIS SIEGELBAUM \\ Michigan State University \\ October 2015
}

\title{
Charles E. Townsend, 1932-2015
}

Charles E. Townsend, a legendary figure in Slavic linguistics, died peacefully at his home on June 7, 2015, surrounded by his family members. He is survived by his wife, Janet, three daughters-Erica, Sylvia, and Louise-five grandchildren, and many grateful colleagues and students who fondly addressed him as "Charlie."

Townsend was born in 1932 and grew up in Vermont and New York. After graduating first in his class from the Trinity School in Manhattan, Townsend pursued an all-Ivy academic career. He graduated magna cum laude in German from Yale and obtained his $\mathrm{PhD}$ in Slavic linguistics under the tutelage of Roman Jakobson and Horace Lunt at Harvard, where he also served as an assistant professor for four years. Townsend then spent four decades at Princeton, most of that time as chair of the Department of Slavic Languages and Literatures. He also taught intensive Russian courses at the Indiana University Slavic Summer Workshop in 1972-81.

Townsend's achievements were remarkable in their quantity, quality, and scope. Though his primary focus was on Russian and Czech, he also taught courses in Polish, Serbo-Croatian, Bulgarian, Old Church Slavonic, and comparative Slavic linguistics. Several of Townsend's books have become classics, appreciated by generations of Slavists, among them Russian Word-Formation (McGraw-Hill, 1968; reprinted by Slavica in 1975), Continuing with Russian (McGraw-Hill, 1970), Czech through Russian (Slavica, 1981; revised and expanded in 2000), A Description of Spoken Prague Czech (Slavica, 1990), and Common and Comparative Slavic: Phonology and Inflection with Special Attention to Russian, Polish, Czech, Serbo-Croatian, Bulgarian (Slavica, 1996; 
published in German in 2000 and Korean in 2011). In over fifty published articles, Townsend addressed an impressive range of issues in Slavic phonology, morphology, syntax, and semantics, exploring the form-function dynamic across the contexts of various literary and spoken registers. A dual purpose prevailed throughout his work: combining intellectual precision with pedagogical application, and demonstrating the role that linguistic description can play in the language classroom. The range of languages Townsend mastered provided the means for his sustained commitment to contrastive analyses of languages.

In 1994, Townsend received the American Association of Teachers of Slavic and East European Languages Award for Distinguished Contribution to the Profession, and in that same year he was made an honorary member of the prestigious Czech Linguistics Society in Prague. In 2002, students and colleagues presented Townsend with a festschrift, Where One's Tongue Rules Well: A Festschrift for Charles E. Townsend, ed. Laura A. Janda, Steven Franks, and Ronald Feldstein (Slavica) on the occasion of his seventieth birthday. In it we expressed "our gratitude for the inspiring ideas, careful mentoring, vigilant feedback, and unflagging friendship with which Charlie has enriched our lives" (1).

Charlie was always an enthusiastic traveler. In 1954, he set sail for Germany and met his future wife, Janet, among the fellow Fulbright scholars on board. After studying Russian at the Defense Language School in Monterey, California, Charlie returned to Germany in 1957-58 with the U.S. Counterintelligence Corps. The following year, he sailed to Italy and then traveled by train through Austria, Germany, Czechoslovakia, and Poland before reaching Moscow, where he served as a guide at the American National Exhibition. In the summer of 1965, Charlie and Janet drove through most of the countries of western and eastern Europe and the USSR. In the course of his career, he delivered invited lectures throughout the United States and in Russia, the Czech Republic, Germany, the Netherlands, Great Britain, and China.

Charlie liked to refer to himself as a "jock." He played varsity football and basketball in high school and took up tennis and squash in Cambridge. He regularly defeated all colleagues and students who were brave (or foolish) enough to face off with him on a court. A lifetime learner, Charlie studied Spanish, Swedish, and Persian in retirement, all of which he mastered to the point that he could enjoy novels in their original languages. Right up until his death, he participated in a German-language book club.

In his later years, Charlie entertained dozens of friends and colleagues with limericks, which he wrote in English, Czech, and Russian and distributed by e-mail. Eight of his limericks written in Czech were published in the Revolver Revue in Prague in 2013. The topics of these literary creations run the gamut from politics to potholes and include odes to his friends and family members, his doctors, and, of course, Slavic languages and linguistics. Here is a sample of items-one in each language-that will surely hit home for students and scholars of Slavic languages:

All hail to Slavic linguistics,

And though I have no real statistics,

When Jakobson speaks

Every girl student squeaks,

And the guys, they just go ballistics.

Čeština řeč elegantní

Má strukturu velmi markantní.

Tak kdo se mu nauči

Přes tolik obtižíi

Má právo být arogantní. 
Я человек недовольный

Не хочу изучать вид глагольный.

Мне никак не понять

Какой вид подобрать

Я пойду играть в теннис настольный.

Charlie was proud to have put in a thousand hours of hospice volunteer work. He compiled a songbook of popular tunes from the 1930s and " 40 s that he would bang out on a piano for patients to sing along with him.

In the last few months of his life, Charlie translated into English a series of love poems penned by the Czech author Eduard Petiška. It seems fitting to close with the last poem he translated, only ten days before he passed away:

Instead of everything suddenly nothing. And this, too, you can read in the unnoticed movement of flowers, when they enter into the first frost

without bees, without fragrance, without color.

The account for the past season

looks as clean as the face of a full moon, only here and there some darkish spots, which resemble neither letters nor numbers, but more like something forgotten.

Is it us, maybe? 